\title{
Chapter 1 \\ Mysteries of the Geological History of the Cenozoic Arctic Ocean Sea Ice Cover
}

\author{
Jörn Thiede
}

\begin{abstract}
The University of the Arctic assembles a large group of northern hemisphere scientific institutions with a huge research capacity due to being the home of a large number of junior scientists with a high potential for the future. The vagueries of the Cenozoic Arctic ice cover history have the potential of contributing to our understanding of future environments on the northern hemisphere. This may have its implications of the socio-economic conditions for the societies inhabiting high northern latitude land areas. Climatic conditions during the young geologic past were sometimes warmer than today; the climate has a „memory“ and such conditions might offer analogues what is in store for the future for all of us.
\end{abstract}

\subsection{Introduction}

The University of the Arctic Congress during September 2016 probably represented the largest assembly of Arctic research institutions, with a huge potential of many junior scientists who would be able - if combining and coordinating their efforts- to contribute to and to tackle a big problem, namely the variable history of the Arctic Ocean ice cover. Even though the mid-nineteenth-century scientists speculated that the modern central Arctic Ocean may be ice-free, we know since F. Nansen's famous crossing of it on his research vessel FRAM 1893-1896 that it is presently almost completely covered by sea ice, with very few larger ice bergs coming from glaciers and ice shelves from the surrounding glaciated shelves and mountain ranges. The past years of intensive stratigraphic studies of sediment cores from the Arctic Ocean have revealed many new data of changes of the Cenozoic Arctic Ocean ice cover through time. Our understanding of its increasingly complex history is growing and contradicts established text-book knowledge in many ways. This article offers to formulate a great scientific challenge; however, it does not offer for an in-depth going synthesis of this exciting time period of global paleoenvironmental history.

\footnotetext{
J. Thiede $(\bowtie)$

Köppen-Laboratory, Institute of Earth Sciences, Saint Petersburg State University,

V. O., Sredniy prospect 41, St. Petersburg 199 178, Russia

e-mail: jthiede@geomar.de
} 


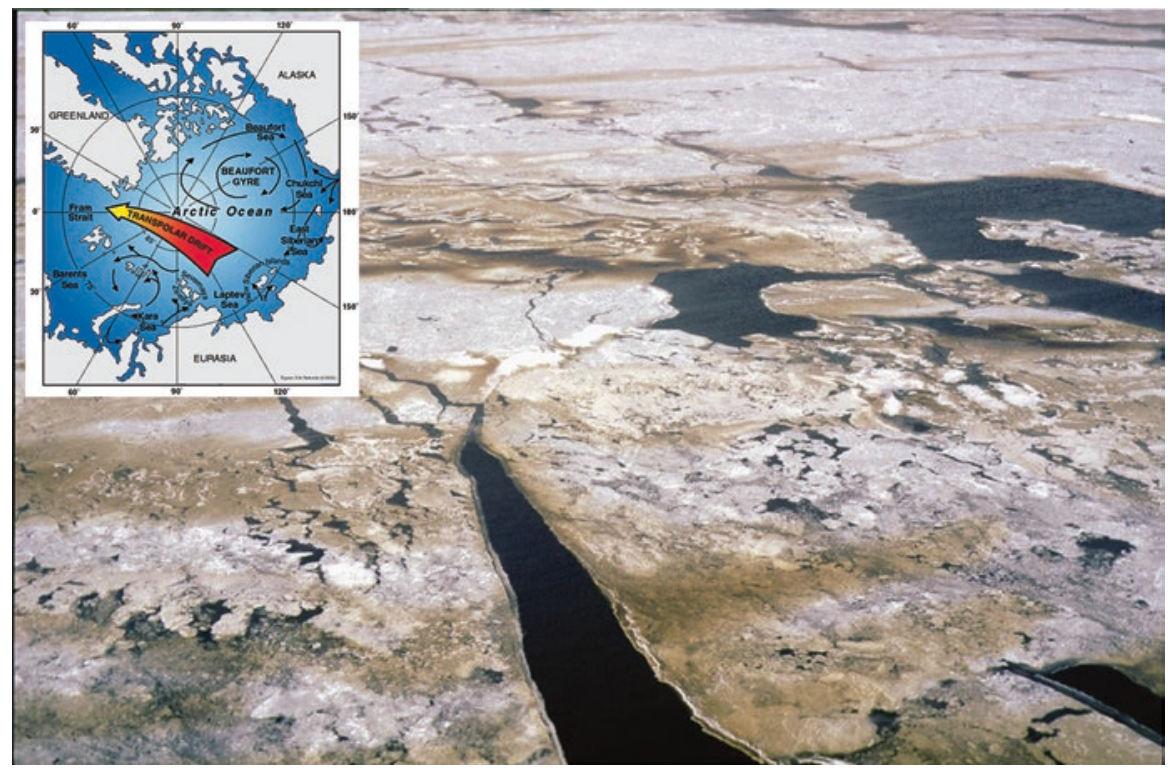

Fig. 1.1 The Eurasian Arctic shelf seas with their important influx of fresh water are considered the „factories“ of the young sea ice, sometimes with large amounts of fine-grained sediments forming "dirty" flows which included into the Transpolar Drift (arrow in the inserted map) travels across the Arctic Ocean to exit mostly into the Norwegian-Greenland Sea through Fram Strait (Photo by H. Kassens, Kiel). The insert map has been adapted from Gorshkov (1983)

\subsection{Dynamics of the Modern Arctic Ocean Sea Ice Cover}

The Arctic sea ice cover (Fig. 1.1) owes its existence to the polar position of the Arctic Ocean with its small solar insolation and hence cold temperatures, as well as its interaction of the continental hinterlands with the ocean. From modern observations we know that the Arctic sea ice cover is presently shrinking under the influence of rising global temperatures; the year 2016 was the warmest one during the recent past and we will probably experience increasingly open waters in the central Arctic Ocean in the near future.

Its history remained almost completely unknown until the modern research ice breakers were capable to visit the central Arctic Ocean, which for the first time was demonstrated by the Swedish YMER-80 expedition (Schytt 1983). In 1987 the German POLARSTERN reached the Gakkel Ridge; in 1991 POLARSTERN and the Swedish ODEN succeeded as the first conventional surface research vessels to attain the North Pole (Fig. 1.2).

The hydrographic properties of the ocean waters and the glaciology of the ice cover could be studied in great detail. It is now clear that the influx of fresh water from the North American and in particular the Eurasian rivers have a major impact on the formation of a shallow brackish water layer on the surface of the Arctic Ocean which supports the sea-ice cover (Fig. 1.3). Because of the peculiar modern 


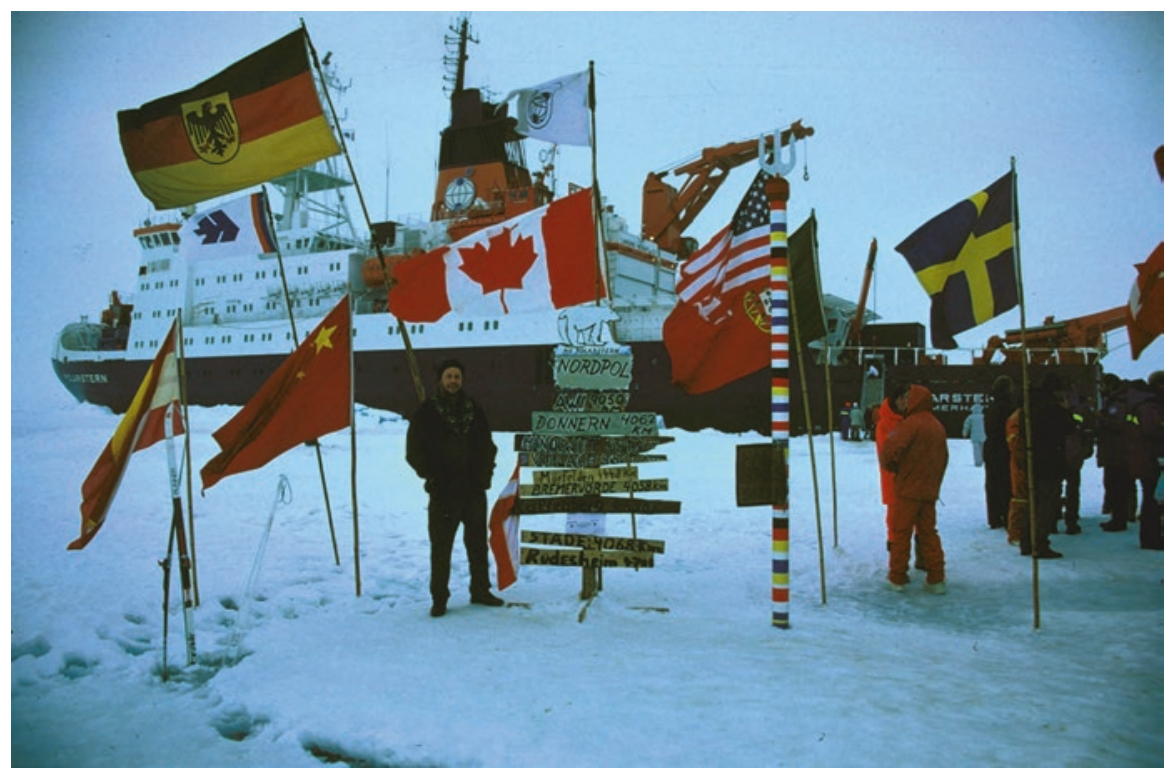

Fig. 1.2 The International ARCTIC Expedition of the Swedish ODEN and the German POLARSTERN reached the North Pole in early September 1991. It demonstrated that the modern infrastructure now available to polar researchers opened up a completely new phase of Arctic Ocean research (Photo by an expedition participant)

drift pattern of the Arctic sea ice (Transpolar Drift -Fig. 1.1, Beaufort Gyre) the Eurasian shelf seas can considered as „factories for the production“ of most of the new sea ice. The formation of this ice can lead to the inclusion of substantial amounts of fine grained sediment materials (Fig. 1.1) which after several melting cycles can concentrate on the ice surface to form ,dirty“, mostly relatively old ice flows.

\subsection{High Variability of Arctic Ocean Ice Covers During the Quaternary}

Maps like those published by Hughes et al. (1977) and CLIMAP (CLIMAP Project Members 1976, see also Cline and Hays 1976) provided widely differing opinions of the nature of the Arctic ocean ice cover without having any field data in support. Figure 1.4 assumes that a huge ice sheet extending from North America and northern Eurasia reached across the entire Arctic Ocean forming a thick ice shelf over the deep-sea regions. The CLIMAP reconstruction (Fig. 1.5), on the contrary, saw the ice sheets both on the North American as well as on the NW Eurasian side limited to the continents and their shelves, with the central Arctic Ocean and the Norwegian Greenland Sea possibly covered by sea ice. 


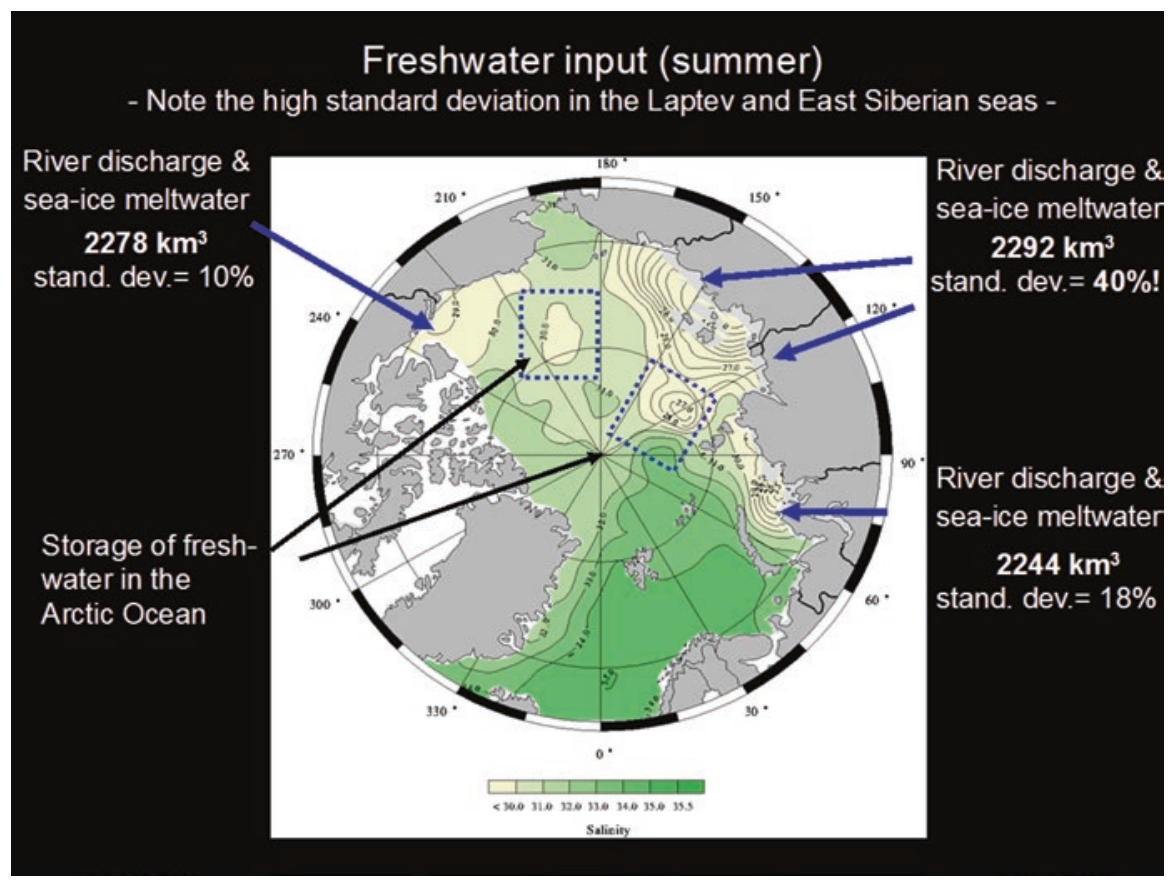

Fig. 1.3 The salinities of the Arctic Ocean surface waters are heavily impacted by the fresh water influx from northern Eurasia. The regional salimity anomalies (isolines are expressed in ppt's) during the summer have been taken from Gorshkov 1983, the corresponding fresh water input has been adapted from EWG (Environmental Working Group) 1998 (Oceanography atlas for the summer period)

Since 1987, research ice breakers have been able to penetrate the Arctic ice cover up to the North Pole, both from the West (Fram Strait and Svalbard) as well as from the Far East (Bering Strait) systematically recovering sediment samples and cores which then allowed to define the impact of the existence of the Arctic ice covers. Based on a collection of sediment cores Spielhagen et al. 2004 have been able to document the presence of the sea ice for the past 120000 years (MIS 1-5), while the intensity of the sedimentation of planktonic foraminifers as well as of the ice-rafted terrigeneous detritus reflected the alterations between glaciations and interglaciations on the adjacent continents. Each time, one of the large glacial ice sheets collapsed during deglaciation, large amounts of fresh water entered the Arctic Ocean and left their imprint in the O-isotope signals preserved in the shell materials of the planktonic foraminifers. Mangerud et al. 2004 also studied the impact of the subglacial lakes whose run-off to the Arctic Ocean had been barred by the glacial ice sheets in North America and NW Eurasia while rivers such as the Lena and others to the East of Taymyr Peninsula (eastern limitation of the Upper Quaternary ice sheets) had been emptying their fresh water into the Arctic Ocean almost continuously during glacials and interglacials. 


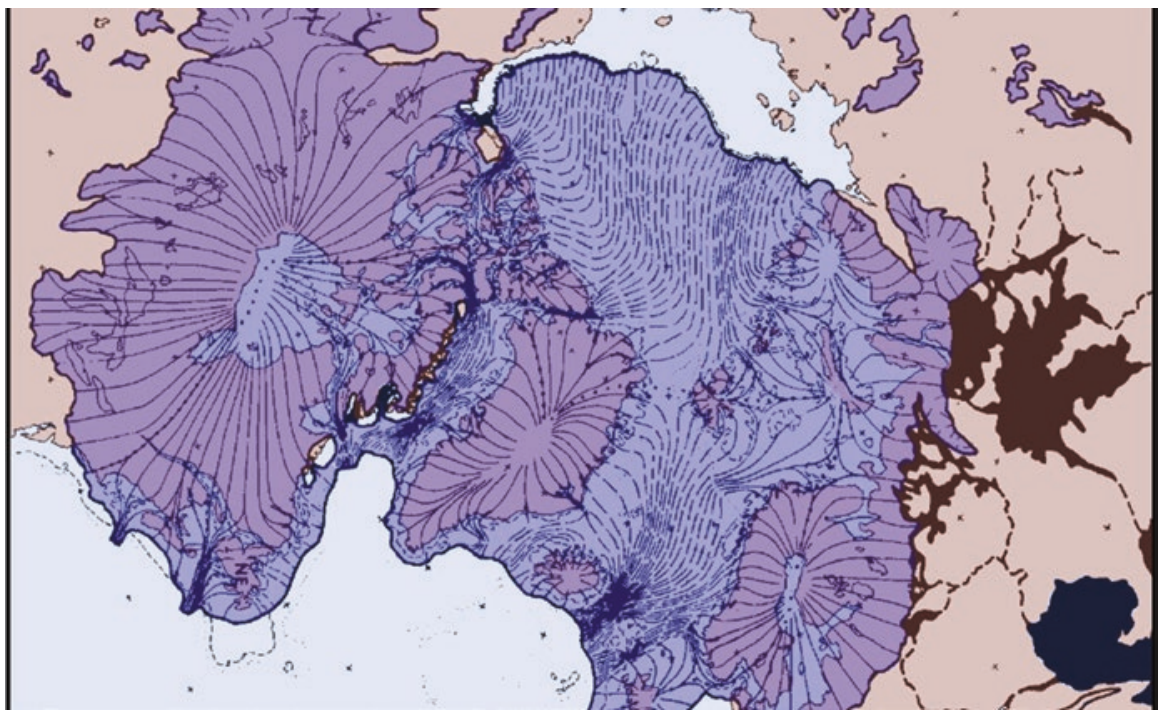

Fig. 1.4 Northern Hemisphere ice cover during the LGM (Last Glacial Maximum) according to Hughes et al. (1977) who assumed the existence of a thick ice shelf over the central Arctic deep-sea basins

This simplified picture changed substantially when the traces of large ice shelves extending into the central Arctic Ocean were detected through glacial erosional features, first on Lomonosov Ridge, later also on several other structural highs in the Arctic Ocean (Jakobsson et al. 2016). This interpretation is based on geophysical evidence from multibeam bathymetry and seismic reflection subbottom profiles. The ice shelves appear to be coeval with MIS 6 which represented the glaciation over NW Eurasia with an ice sheet substantially larger than the younger ice sheets which had been mapped by Svendsen et al. 2004 (cf. Thiede et al. 2004) as their contribution to the QUEEN project.

It would be highly desirable to learn more about the Cenozoic, in particular the early Pleistocene history of the Sibirian river run-off to the Arctic Ocean, because of its influence on the Arctic Ocean surface water salinities. There are well developed river terrace systems from East Siberian rivers such as the Lena and it is hoped that they will be studied intensely in the future (Savelieva et al. 2013). The Quaternary history of this region and of the bed of Lena river in this region is poorly known, but of particular interest, since an extension of the Russian railroad system has been established along the eastern shores of the Lena River; it is probably in the vicinity of Yakutsk (capital of the republic of Sakha) where the first bridge ever will cross the most important, longest and undisturbed Siberian river draining into the Arctic Ocean. 


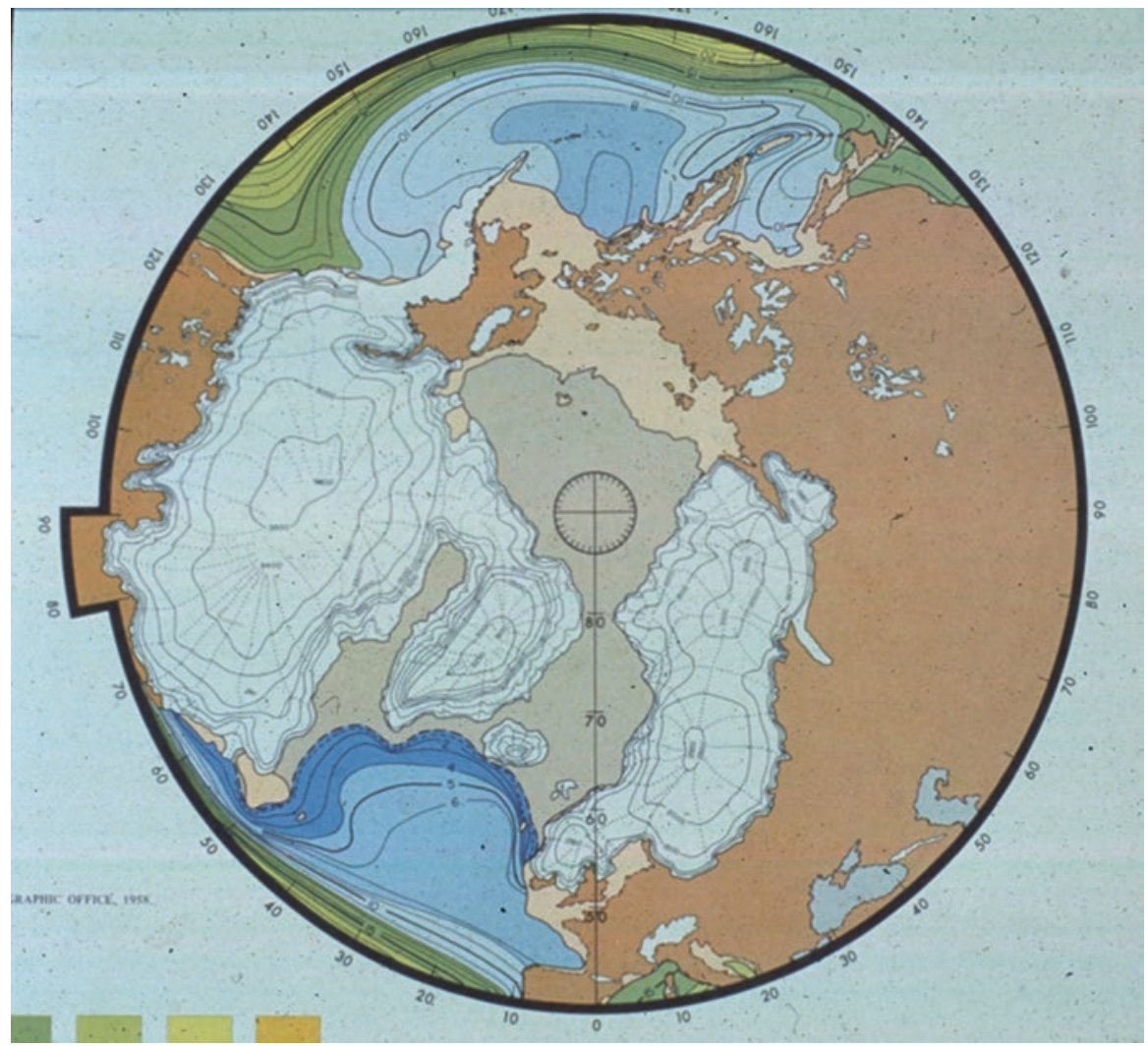

Fig. 1.5 The CLIMAP reconstruction (CLIMAP Project Members 1976; see also Cline and Hays 1976) of the last glacial maximum (LGM) on the Northern Hemisphere. Contrary to Hughes et al. (1977) the central Arctic Ocean was considered sea ice covered, even this could only be proven much later after expeditions of research ice breakers successfully reached the central Arctic Ocean (Spielhagen et al. 2004)

\subsection{The Enigma of the Tertiary Predecessors of the Central Arctic Ocean Ice Covers}

Already Köppen and Wegener (1924) based on observations from northernmost Siberia had vaguely assumed that Cenozoic northern hemisphere glaciation reached back into the Miocene. This assumption could be confirmed by the activities of the deep-sea drilling project in the Norwegian-Greenland Sea (DSDP/ODP Legs 38, 104 and 151), the two latter legs recovering completely cored Lower and Upper Tertiary sediment sequences (Thiede 2011a, b). In the Norwegian-Greenland Sea and in the drill sites around Greenland indications of continuous ice-rafting of coarse terrigenous sediment components suggested that ice-bergs were present in 
this area since Paleogene times which while melting shed their sedimentary load to the seafloor.

The JOIDES RESOLUTION was the first scientific drilling vessel which succeeded -accompanied by the heavy duty ice-breaker FENNICA- to enter the Arctic Ocean and recover sediment cores from the Neogene and Pleistocene sediment cover of the Yermak Plateau to the North of Svalbard (Thiede, Myhre et al. 1996). A most spectacular record of ice-rafted fine- and coarse grained terrigeous has been obtained by the IODP Expedition 302 ARCTIC CORING (ACEX) of ECORD in 2004 when a flotilla of three ice breakers reached a position on Lomonosov Ridge very close to the North Pole (Backman and Moran 2009). Figure 1.6 is reflecting the analyses of the shipboard sedimentologist St. John (2008) with observations af variable concentrations of coarse and fine-grained ice rafted detritus since Late Eocene times. The precise age of the onset of ice-rafting in the Upper Eocene sediments is still a subject of debate (Poirier and Hillaire-Marcel 2011) but it is clear that this happened much earlier than assumed hitherto (apparently also earlier than the onset of Antarctic glaciation). A similar very early onset was later confirmed at ODP Site 913 immediately to the East of Greenland.

The presence of the coarse grained ice-rafted sediment components suggest the occurrence of ice-bergs originating from glaciers or ice-shelves which reached into the ocean. This cannot be said to easily for the finegrained materials which can also

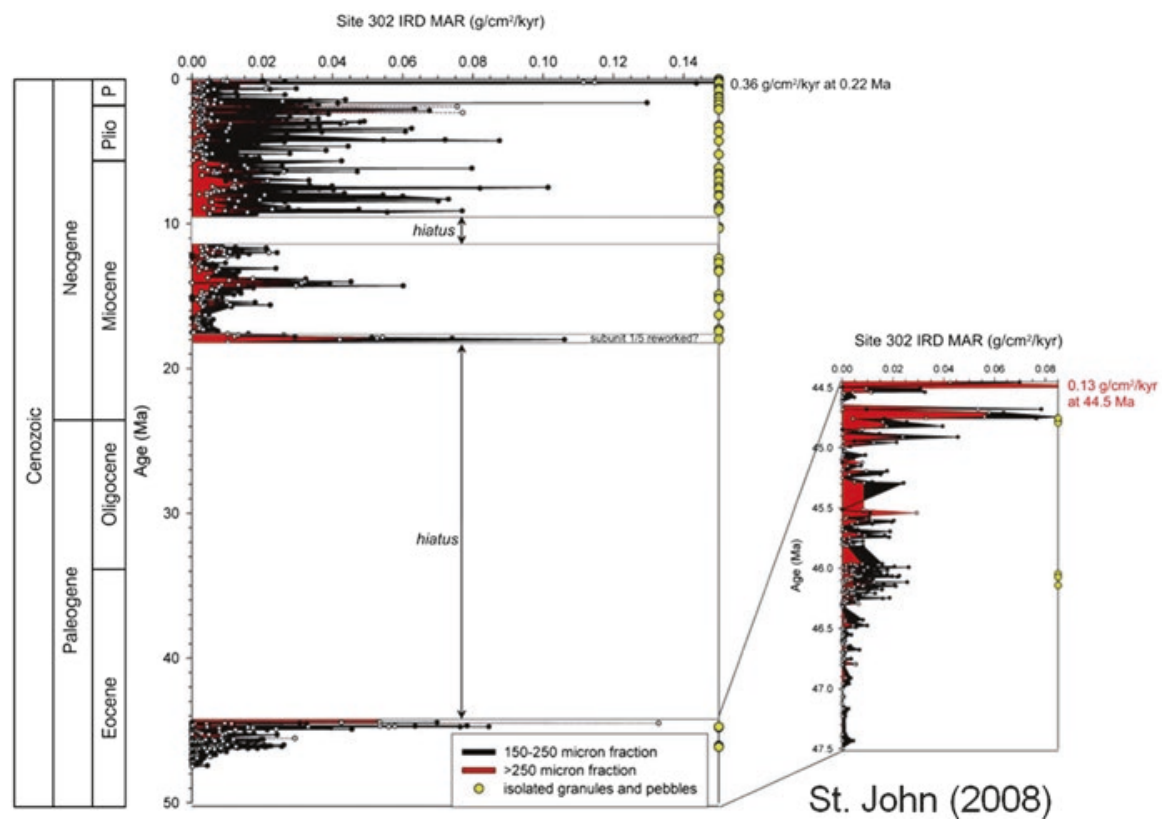

Fig. 1.6 The Lomonosov Ridge ice-rafting record from Eocene through Quaternary times deduced from sediment components (St. John 2008). The yellow circles mark the occurrence of relatively coarse terrigenous deposits indicative of ice bergs. Age scales on the left; a hiatus marks a missing sediment record 
be brought in by sea ice. Other researchers have therefor argued, based on proxies such as $\mathrm{IP}_{25}$ for spring sea ice cover and alkenone-based summer sea-surface temperatures $>4{ }^{\circ} \mathrm{C}$ that the central Arctic was only seasonally ice-covered (Stein et al. 2016) during the Late Miocene.

The same applies to Upper Cretaceous biosiliceous laminated sediments which had been collected many years ago from Alpha Ridge. Their microfossils seemed to indicate summer sea surface temperatures of $10-15^{\circ} \mathrm{C}$, but later detailed analysis of the laminations documented the presence of thin sand layers in between suggesting ice-rafting by winter sea ice and hence documenting a strong seasonal difference (Davies et al. 2009).

\subsection{What Triggered the Onset of Northern Hemisphere Glaciations During the Paleogene?}

This question leaves room for speculations, but the idea of seeking a relationship between tectonism to the origin and history of continental drainage systems and Arctic climate is by no means new (pers. comm. Hayes 1996; Molnar and Tapponier 1975; Ruddiman \& Kutzbach 1989) even though the available stratigraphies and the timing of events have completely changed over the past 20 years.

Brinkhuis et al. (2006) have published a paleogeographic map for the Eocene Arctic Ocean, when the occurrence of Azolla-microspores in the ACEX-drill cores from Lomonosov Ridge suggested substantially warmer temperatures than later. In modern times Azolla is a floating fresh water fern, mostly lives in subtropical fresh water environments.

During the Eocene, the Arctic Ocean was connected to the world ocean only through shallow sea ways. The Turgay Strait across western Siberia linked the Arctic Ocean with the Tethyan system further to the South suggesting that the Siberian platform at that time was not tipping to the North. Azolla has also been observed in Eocene drill cores in the Norwegian-Greenland and Labrador seas, apparently recording a very strange event of large amounts of fresh water entering the high northern latitude seas.

The deposition of the Azolla-rich sediments preceded the onset of ice-rafting in the ACEX-cores and it is tempting to link the onset of northern hemisphere glaciation to the plate tectonic processes occurring at the southern margin of the Eurasian Plate resulting in the generation of a northward flowing drainage system emptying into the Arctic Ocean (Fig. 1.7). 

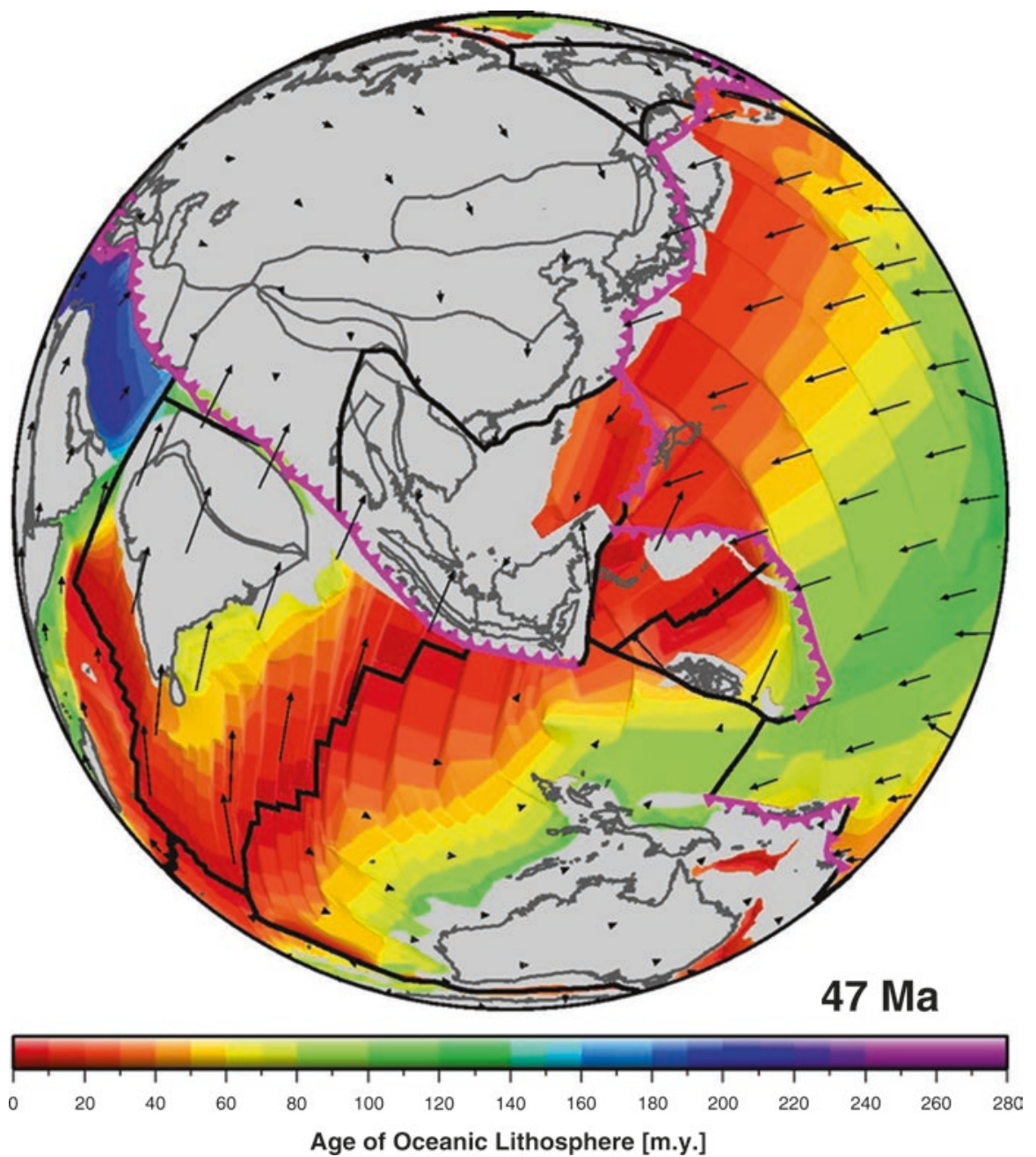

Fig. 1.7 The late Mesozoic and early Cenozoic plate tectonic development resulted in the collision of the Indian subcontinent with the Southern Eurasian plate margin with important consequences for the physiography of the Siberian platform which developed since that time a river system almost exclusively draining into the Arctic Ocean (figure via personal communication of D. Müller, Sydney). The age distribution of the deep ocean floors can be deduced from the distribution of well-dated magnetic anomalies which have been mapped in the global ocean and which allow to define the plate tectonic evolution

\subsection{Conclusions}

No question: The Late Mesozoic and Early Tertiary Arctic Ocean was ice-free at times, despite the occurrence of "glendonites“ (mineral formations indicative of cold temperatures) in Upper Cretaceous and Paleogene sediments around the Arctic. 
Nobody knows where and precisely when or why the onset of Cenozoic Northern Hemisphere glaciation occurred, but certainly much earlier that believed up to now! Urgent research needs comprise of systematic future Arctic deep-sea drilling with good areal coverage based on solid and detailed site surveys and a resolution of Siberian river histories, and also involve a courageous young generation of polar geoscientists because to resolve this exciting period of northern hemisphere paleoenvironmental history will take decades.

The University of the Arctic is the largest gathering of young polar scientists and provides the logical and best platform to identify motivated, internationally oriented and well educated junior scientists to achieve this goal.

\section{References}

Backman J, Moran K (2009) Expanding the Cenozoic paleoceanographic record in the Central Arctic Ocean. IODP Expedition 302 synthesis. Centr Europ J Geosci 1:157-175

Brinkhuis H, Schouten S, Collinson ME et al (19 add. co-authors and Expedition 302 Scientists) (2006) Episodic fresh surface waters in the Eocene Arctic Ocean. Nature 441: 606-609

CLIMAP Project Members (1976) The surface of the ice-age Earth. Science 191(4232):1131-1137

Cline RM, Hays JD (eds) (1976) Investigation of Late Quaternary paöepceanography and paleoclimatology. Geol Soc Amer Mem 145:464 (Boulder, CO)

Davies A, Kemp AES, Pike J (2009) Late Cretaceous seasonal ocean variability from the Arctic. Nature 460:254-258

EWG (Environmental Working Group) (1998) Oceanography atlas for the summer period. University of Colorado, Boulder, version 1.0. CD from User Services NSIDC/CIRES, Boulder, $\mathrm{CO}$

Gorshkov SG (ed) (1983) World Ocean Atlas. Vol. 3. Arctic Ocean.- 184 pp., (Pergamon Press) (copyright Dept. Navig. Oceanogr., USSR Ministry of Defense) Leningrad (in Russian with annotation in English)

Hughes TJ, Denton GH, Grosswald MG (1977) Was there a late Würm Arctic ice sheet? Nature 266:596-602

Jakobsson M, Nilsson J, Anderson L et al (22 add. co-authors) (2016) Evidence for an ice shelf covering the central Arctic Ocdan during the penultimate glaciation. Nat Commun 7: 10.1038/ ncomms 10365

Köppen W, Wegener A (1924) Die Klimate der Geologischen Vorzeit/the climates of the geological past. In: Thiede J, Lochte K, Dummermuth A (eds) Introduction by the editors, reprint and new translation into English. Borntraeger Science Publishers, $657 \mathrm{~S}$

Mangerud J, Jakobsson M, Alexanderson H et al (11 add. co-authors) (2004) Ice dammed lakes and rerouting of northern Eurasian drainage duriing the last glaciation. Quat Sci Rev 23: $1313-1332$

Molnar P, Tapponier P (1975) Cenozoic tectonics of Asia: effects of a continental collision. Science 189:419-426

Poirier A, Hillaire-Marcel C (2011) Improved Os-isotope stratigraphy of the Arctic Ocean. Geophys Res Let 38:L14607. doi:10.1029/2011GL047653

Ruddiman WF, Kutzbach JE (1989) Forcing of late Cenozoic Northern Hemisphere climate by plateau uplift in southern Asia and American West. J Geophys Res D15:18409-18427

Savelieva L, Bolshyanov D, Thiede J (2013) Среднее течение р. Лена - Нижний Бестях Майя - Эдейцы - Бестях.- (LENA-Expedition 2013).- Report Köppen-Laboratory SPbGU, 15 pp., 8 .figs., Saint Petersburg (in Russian) 
Schytt V (1983) YMER-80: a Swedish expedition to the Arctic Ocean. Geogr J 149(1):22-28

Spielhagen RF, Baumann KH, Erlenkeuser H et al (4 add. co-authors) (2004) Arctic Ocean deepsea record of northern Eurasia ice sheet history. Quat Sci Rev 23: 1455-1483.

St. John K (2008) Cenozoic ice-rafting history of the central Arctic Ocean: terrigenous sands on the Lomonosov Ridge, -Paleoceanography, 23, PA1S05, doi:10.1029/2007PA001483

Stein R, Fahl K, Schreck M (10 add. co-authors) (2016) Evidence for ice-free summers in the late Miocene central Arctic Ocean. Nat Commun 7(Art. nr: 11148): doi:10.1038

Svendsen JI, Alexanderson H, Astakhov V et al (27 add. co-authors) (2004) Late Quaternary ice sheet history of northern Eurasia. Quat Sci Rev 23:1229-1271

Thiede J, Myhre AM, Firth JV, Shipboard Scientific Party (1996) Proceedings ODP, Scientific Results 151: 685 pp., (Ocean Drilling Program) College Station, TX

Thiede J, Astakhov V, Bauch H et al (9 add. co-authors) (2004) What was QUEEN? Its history and international framework. Quat Sci Rev 23:1225-1227.

Thiede J, Jessen C, Kuijpers A, Mikkelsen N, Nørgaard-Pedersen N, Spielhagen RF (2011a) Million years of Greenland Ice Sheet history recorded in ocean sediments. Polarforschung 80(3):141-159

Thiede J, Eldholm O, Myhre A (2011b) Deep-sea drilling in the Norwegian-Greenland Sea and Arctic Ocean. In: Spencer AM, Gautier D, Stoupakova A, Embry A, Soerensen K (eds) Arctic petroleum geology. Geological Society, London, pp 703-714

Open Access This chapter is licensed under the terms of the Creative Commons Attribution 4.0 International License (http://creativecommons.org/licenses/by/4.0/), which permits use, sharing, adaptation, distribution and reproduction in any medium or format, as long as you give appropriate credit to the original author(s) and the source, provide a link to the Creative Commons license and indicate if changes were made.

The images or other third party material in this chapter are included in the chapter's Creative Commons license, unless indicated otherwise in a credit line to the material. If material is not included in the chapter's Creative Commons license and your intended use is not permitted by statutory regulation or exceeds the permitted use, you will need to obtain permission directly from the copyright holder.

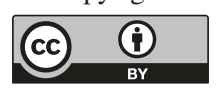

